\title{
Realm of Malay Civilization: Ethnoparenting, Habitus, and Cultural Contestation in Early Childhood Education of Sambas Malay Society
}

\author{
Bayu Suratman, ${ }^{1 *}$ Mahmud Arif $^{2}$ \\ 1, 2Universitas Islam Negeri Sunan Kalijaga, Yogyakarta - Indonesia
}

\begin{abstract}
This article discusses how Sambas Malay parents carry out ethnoparenting and early childhood education to early childhood. Sambas Malay society are relatively traditional who still maintain the value system embraced by the local community. Ethnoparenting in this paper has the meaning of parenting performed by a particular ethnicity or tribe through the culture adopted. This research was conducted by the qualitative method through a sociological approach to education. The data was obtained through interviews and in-depth observations in Batu Makjage Village, Tebas District, Sambas Regency, West Kalimantan Province. Some habitus in ethnoparenting Sambas Malay society in educating early childhood include tunjuk ajar, pantang larang, kemponan and any tradition. Obstacles in ethnoparenting in the form of contestation of the value of Sambas Malay culture with modernity. The contestation that occurred experienced dislocation and resulted in the social change of Sambas Malay society and changed the habitus and urban lifestyle that has dominated in the ethnoparenting of Sambas Malay society.
\end{abstract}

Artikel ini mendiskusikan tentang bagaimana etnoparenting dan pendidikan anak usia dini yang dilakukan orangtua Melayu Sambas kepada anak usia dini. Orang Melayu Sambas tergolong tradisional yang masih mempertahankan sistem nilai yang dianut oleh masyarakat setempat. Etnoparenting dalam tulisan ini mempunyai arti pengasuhan yang dilakukan oleh suatu etnis atau suku tertentu melalui budaya yang dianut. Penelitian ini dilakukan dengan metode kualitatif melalui pendekatan sosiologi pendidikan. Data diperoleh melalui hasil wawancara dan observasi yang mendalam di Desa Batu Makjage Kecamatan Tebas Kabupaten Sambas Provinsi Kalimantan Barat. Beberapa habitus dalam etnoparenting orang Melayu Sambas dalam mendidik anak usia dini meliputi tunjuk ajar, pantang larang, kemponan dan tradisi lainnya. Hambatan dalam etnoparenting berupa kontestasi nilai budaya Melayu Sambas dengan modernitas. Kontestasi yang terjadi mengalami dislokasi dan berakibat pada perubahan sosial orang Melayu Sambas dan merubah habitus serta gaya hidup urban yang telah mendominasi dalam etnoparenting orang Melayu Sambas.

Keywords: ethnoparenting; early childhood education; Sambas Malay

*Corresponding Author: Bayu Suratman (bayuseladu@gmail.com), Jl. Laksda Adisucipto, Depok, Sleman, Daerah Istimewa Yogyakarta 55281, Indonesia. 


\section{Introduction}

The people of West Kalimantan have a lot of local wisdom that includes values or a set of unwritten rules about behaving and interacting in everyday life and melting with the religion, one of them Islam (Prasojo, Elmansyah, and Haji Masri 2019:218-19). One of society's flexible characteristics with Islamic teachings that quickly assimilated with the existing culture in West Kalimantan and resides in daily life is Malay. According to Frank Swettenham's view who assumed the Malay community is a follower of the Prophet Muhammad and believes in destiny, but also believes in superstition (Swettenham 2003:2). This can be seen from some beliefs of the West Kalimantan Muslim community who still carry out local traditions (Kurniawan 2015; Salim 2012:22). One of the areas in West Kalimantan that still carries out tradition and culture is Sambas.

In 1999 Sambas had suffered conflict which involves fellow Muslims from different ethnicities (De Jonge and Nooteboom 2006:46061; Klinken 2007:53-71). That was a communal violent conflict having a widespread impact (Fernando and Marta 2019; Schulze 2017; Stewart 2002). The experience of the conflict has not discouraged Sambas Malay society from upholding the value system. It had been maintained until nowadays. Sambas Malay value system even embedded strongly into society culture that finally shapes and influences society members personality.

Mostly of Sambas ethnic members are Malay people. Sambas has historical roots in the spread of Islam in West Kalimantan. The first mosque in West Kalimantan was built in Sambas during the
Sambas kingdom (Zein 1999:318). Islamic teachings thickly dominate Sambas Malay culture. It can be shown in the everyday life of Sambas people and the building culture that shows the manifestation of Sambas Malay identity. Some scholars, as Hermansyah (2015:1) and Yusriadi (2015:97, 2018b:13) mentioned Malays, the follower of Islamic teachings. Besides, Islam is a marker of one's identity. Malay and Islam are inseparable synonyms because they have become Malay's identity.

Nowadays, Sambas society is experiencing changes in education, religion, culture and society. Sambas Malay society is divided into two groups: in one hand is the Malay people who still carry out traditions, customs, local wisdom; and in the other hand is the Malay people who abandoned the old customs. The former group usually called as agrarian Malay and the latter as industrial Malay. Factually they are all rice farmer (Kurniawan and Suratman 2018:51-59). The agrarian Malay cultivate rice fields traditionally, do not introduce technology in their work, and have some belief pertaining to the time for clearing the field and harvest.

Meanwhile, the industrial Malay community introduces technology in their rice field cultivation and is open to information waves. Nowadays so much changes among Sambas society: in education, religion, culture, and society. Social changes in Sambas Malay society positively impact to the social life, including parenting and early childhood education. Agrarian Malay people tend to use traditional procedures in educating children from an early age. 
Based on Yusriadi research (2018a: 163-72), Malay in Sambas is divided into two, namely: New Malay and Old Malay. The term new Malay is more directed to people who have just entered Malay, where they were previously referred to as Dayak people, Chinese, and others. This tribal change was caused by religious conversion, which resulted in tribal identity also changing. Old Malay refers to people born to parents who have claimed to be Malay and have been integrated in Malay culture. The changes that occurred certainly experienced the emergence of a new culture among the Sambas Malay society, be it from birth to death; the Sambas Malay society has its tradition or life cycle of Sambas Malay society. The values that have been embedded in people's lives have shifted, which resulted in changes in people's behavior, especially in the younger generation. However, not a few Sambas Malay societies still maintain religious traditions in the community. The implementation of traditions carried out by the community becomes a value system and becomes a means of education for the community.

Internalization of local cultural values such as Ethnoparenting in Sambas provides space in shaping the existing value system in the Sambas Malay society. The author mentions the term ethnoparenting in this paper has the meaning of parenting performed by a particular ethnic or tribe through a culture that is embraced in a down-and-down way. In this context, ethnoparenting discusses the traditional model of parenting and early childhood education and local wisdom of the Sambas Malay ethnicity. As is known, Sambas Malay is still living the tradition, mostly from the village area. When educating early childhood, Sambas Malay people still maintain cultural values that take place in the community. Education in society positively affects the perspective and mindset instilled in children early (Masmuri and Bayu 2019:13). Internalization of cultural values in Sambas Malay people also significantly influences the concept of early childhood education carried out. Attitudes and responses instilled in cultural values are parents' efforts to bequeath culture in the period of child development when perceived as adults. Especially at this time Sambas Malay society experienced a contest between the progress of the times by maintaining the culture and value system that has been formed so that it changes the conduct of early childhood education (Suratman 2019).

One of the areas that still maintains the value of daily culture, including educating children, is Batu Makjage Village. Sambas Malay society in Batu Makjage Village adheres to a bilateral or parental kinship system by adopting an extended family system through the lineage of male and female ancestors together (Soekamto 1993:56). The extended family system is the core family plus important siblings such as, grandparents, aunts, uncles, and others (Hartini and Kartasapoetra 2007:140). Besides, the Sambas Malay society's condition in Batu Makjage Village belongs to the village community that still belongs to the traditional Malay category as followers of Muhammad who still carry out the ancestral tradition (Hermansyah 2010; Wahab 2013:89-97).

There are some researchers have studied Malay culture, as Rizal Mustansyir (2015), Adnan Mahdi (2019), Syamsul Kurniawan 
(2015, 2018), Moh. Haitami Salim (2013). A review of the library was conducted to see the extent of research on early childhood education of Sambas Malay people as well as show the novelty side of this study. The research focused only on Malay and local culture in general. Meanwhile, this study discusses early childhood care in Sambas Malay family which still maintains cultural value in practice. However, parenting experienced cultural contests and there was a shift in values in the lives of Sambas Malays in the era of globalization. This article departs from a qualitative study with an educational sociological approach where the data are obtained from observations in Batu Makjage Village and interviews to several Sambas researchers and the community of Batu Makjage Village, Tebas Subdistrict sambas, an administrative located in West Kalimantan Province.

\section{Habitus Sambas Malay in Early Childhood Education}

Habitus is a scheme obtained by the agent through dismantling the circumstances faced by the agent and conditioning the situation faced by the agent through internalization of external restraints and various possibilities. It means habitus is a shared experience shared by the agent as the subject even though it has their uniqueness (Bourdieu 2008:54, 2012:xvi). Habitus covers all kinds of cultural activities: production, perception, and evaluation of the practices of daily life. Social practices that occur in Batu Makjage Village in this case the Sambas Malay family environment, has a way of educating children through instilled values. Of course, this parenting pattern the author calls the term culture in Sambas Malay society's family environment. Through culture, early childhood education is a set of values, beliefs, perspectives, rituals, and institutions of a group or population. The group can be small in shapes, such as neighbors, schools, or large-shaped communities such as race, ethnicity, and social status groups. Culture provides a way of seeing the world and togetherness with other influences, determining patterns of everyday feelings and behaviors. Culture is a dynamic impulse that responds to social, political, and economic events and shapes its meaning. Culture provides developmental niches that include: 1) physical and social background for parents and children, 2) psychological characters valued by parents and children, 3) recommended behaviors for family members. Therefore, culture forms a wide range of parenting behaviors from parents' general values to the real aspects of daily life where children can eat and sleep (Brooks 2011:127). Parenting through culture in the family has an essential role in determining itself (read: child) in the social environment. The value is instilled into the habitus through various applications in the internalization of value. Habitus internalized by Sambas Malay society in early childhood education through several strategies or methods, namely as follows:

\section{Early Childhood Education through Tunjuk Ajar}

Tunjuk ajar is a method of parenting carried out by Sambas' parents. This strategy is a traditional parenting pattern carried out by Sambas Malay society in a down-and-down way. In Sambas Malay, society knows the tunjuk ajar as a model of early childhood education in the 
family's scope. Tunjuk ajar has a philosophical meaning when educating children, namely by appointing children after being appointed and then the child is taught. Appointing a child is only a symbol meaning the child is commanded and after that the next child is given teaching. The model of tunjuk ajar in early childhood education for Sambas Malay society is carried out in the family environment (Interview of Mr. Adnan Mahdi, February $1^{\text {st }}$ 2020). In Sambas Malay society, tunjuk ajar is also divided into three, namely, as follows:

\section{Tunjuk Rasa}

Tunjuk rasa is part of the tunjuk ajar where in the implementation of child care in Sambas Malay society's family environment. Tunjuk rasa is defined as a form of parental affection in educating children in the form of the way children are stimulated, children are hugged, do not commit violence and others. The intention in tunjuk ajar in Sambas Malay society, especially in Batu Makjage Village, is a kind of warmth shown by parents through children's treatment. The purpose of tunjuk ajar in early childhood education of Sambas Malay society is to become obedient and obedient to parents. The value instilled through tunjuk ajar is one of the values of compassion in mental and spiritual fulfillment. Fitrah every child has a conscience that parents can develop, one of them with tunjuk ajar (Nurbayani 2015:70). Sambas Malay parents' treatment in Batu Makjage Village towards their children is like treating the child physically well, the most important part of the attachment process between the child's parents. Attachment between parent and child occurs through direct contact with affection. The value of affection is internalized to the child is carried out with tunjuk ajar or with a behavior that is affectionate to the child (Polcari et al. 2014:92). The child's attachment is an eternal bond that binds the child with his parents and becomes security for them. In his view, there are at least four important contributions in the attachment of the child, namely: Sensitivity (the ability to understand the child's signals accurately and respond appropriately and quickly); Togetherness (positive harmony and mutual relationships); Synchronization (coordinated social interaction); and Positive attitudes (emotional expression, acceptance, and pleasure in children) (Brooks 2011:392-93).

Tunjuk rasa performed by Sambas Malay people is identical to the William Sears attachment parenting model in Granju and Kennedy (1999:xix), who mentions attachment parenting examples by sleeping with children. There are at least five William Sears attachments that are identical to the care of Sambas Malay people in Batu Makjage Village, namely: 1) Bonding, attachment to children at birth; 2) breastfeeding; 3) bed-sharing, sleeping together; 4) babywearing, holding the baby with a sling; and 5) belief, believing that a child's crying is an important signal. Playing together is a way for parents to show their sense to early childhood. Based on the observations made that tunjuk rasa influences children's development. Children are more likely to be close to parents, and socially, the child is also easily social, especially with family members at home. In addition, children are easily familiar both with neighbors and with peers. 


\section{Tunjuk Lafal}

One of the tunjuk ajar applications by using tunjuk lafal is to teach children when they are early years, especially as infants by inviting children to talk, children to be sung, chanting dhikr, and watering. For the view of Sambas Malay society, ask children to talk, sing children when they want to sleep, or read shalawat when the child cries are called tunjuk lafal (interview with Adnan Mahdi, February, 1st 2020). Based on researchers' observations during a visit at one of Sambas Malay society's houses, parents when feeding food to children by inviting their children to talk even though their child is still a baby.

Indeed, tunjuk lafal is a habit that is often done by Sambas Malay parents in Batu Makjage Village to early childhood to invite to talk, chant dhikr while hugging children (tunjuk rasa). Sambas Malay society, especially in educating early childhood in the family environment, trains children to communicate in infants. Parenting by inviting children to talk or speak is done by Sambas Malay parents in Batu Makjage Village when the child wants to eat, sleep, cuddle children, etc. The purpose of inviting children to talk or teaching through pronunciation (tunjuk lafal) to train children to be articulate so that children have a jerampah attitude (friendly). Concerning this, Jane Brooks explained the cultural model in parent-child relationships as done by Sambas Malay parents in Batu Makjage Village through communication in child development. Children have an attitude of independence, and in verbal emphasis, the child has an empathy attitude. Tunjuk lafal carried out by the Sambas Malay society is applying cultural values carried out in the family environment. Communication or conversation conducted by Sambas Malay parents includes building a collaborative family atmosphere. Talking about what is done to the child can build up what is thought, felt, and what is happening to the child. Early childhood discussions are important even though children still can not understand certain words (Brooks 2011:165). Besides, tunjuk lafal is also carried out by Sambas Malay society in Batu Makjage Village by telling stories to children through folklore and is part of parents' contribution in cultural inheritance. Folklore and fairy tales teach children about values, celebrations, history, traditions, and other forms of culture. Folklore gives children authentic information in instilling cultural values and bequeathing that culture to early childhood (McLean 1997:2-3).

\section{Tunjuk Laku}

Tunjuk laku is parents' behavior in giving teaching by instructing children and giving examples of good deeds. An example of tunjuk ajar in Sambas Malay society in Batu Makjage Village when parents send their children to perform prayers; parents also perform prayers together with children (Interview of Adnan Mahdi, February 1sst 2020). Tunjuk laku applied in educating and nurturing early childhood in Sambas Malay society is done through deeds and exemplifies directly (Dumais 2006:85-86). Of the three parenting models, tunjuk rasa, tunjuk lafal, and tunjuk laku, it is part of ethnoparenting. It has become a habitus of Sambas Malay people in parenting given to children from an early age.

\section{Early Childhood Education through Pantang Larang}

In the perspective of Sambas Malay society pantang larang has the meaning of abstinence or prohibition that is used as a benchmark in life by the Sambas Malay society, both related to rites 
and life cycles of Sambas Malay society (birth, marriage, and death) as well as religious and cultural rituals in Sambas Malay society (Aslan 2017:15). Pantang larang is an oral expression that is present in a decreased and decreased abstinence and prohibitions conveyed by the previous containing wisdom and value requirements (Kurniawan 2018:97-98). Sambas's Malay pantang larang beliefs are also exactly the same as Ghanaian society that pantang larang related to early childhood also applies there. It is based on Otoo, Habib, and Ankomah (2015) research that since pregnancy Ghanaian society has limited itself to restrictions such as not being allowed to eat plantains, then the baby will be soft.

Besides, pregnant women should not drink milk because it will cause labor difficulties and many other examples. If viewed in a sense, then the pantang larang consists of two words: pantang and larang. In terminology, abstinence is a rule of conduct and even a prohibition in actions carried out by individuals and groups of people considered taboo. Of course, what the Sambas Malay society does in educating children still uses local wisdom. In the islamic element of Malay religion, pantang larang is not found. However, from the interview results, pantang larang talks about ethics instilled in children by parents. Of course, in some people this is considered absurd, even considered shirk. The Sambas Malay society's daily life knows the various devices, advice, prohibitions, and restrictions given by the oldest people, be it grandparents, fathers, and mothers to give to their children and grandchildren. If violated, there will be consequences for the person (Interview with A. Muin Irkam, February $7^{\text {th }} 2020$ ).
Malay people in Batu Makjage Village consider that pantang larang is used as a reference to build the character value of Sambas Malay society. Pantang larang is part of Sambas Malay culture, in this case, applied in educating early childhood. Pantang larang prohibited in the family environment instilled to early childhood will become habitus in the child's life. When children play outside the house, parents apply restrictions to children such as not playing with knives because they worry about being impaled on friends who are influenced by spirits. Children who tend to accept pantang larang are prohibited from applying it because they fear the calamity that befalls them. Daily activities of early childhood in Batu Makjage Village are carried out outside the house. When the child's parents go to the house, the child lives with his grandmother and plays around the house. When the child's parents go to the house, the child lives with his grandmother and plays around the house. Pantang larang is instilled to limit children's dangerous activities when left by their parents to the rice fields. Therefore, pantang larang will become a habitus in early childhood so that in everyday life will bring what has been instilled by parents to the child. Habitus instilled through abstinence will be in the production, perception, and evaluation of the practice of daily life of early childhood. The habitus will seep into the child's mind, feelings, and aesthetics to influence and determine the value of early childhood tastes based on the taste (flavor) of parents through pantang larang. Pantang larang instilled will be embedded through social space and reflect a person in the social (Bourdieu 2008:54). In this process, education can be considered a fundamental cultural activity in Sambas Malay society's life (Arif 2015:81). 


\section{Early Childhood Education through Kemponan}

Kemponan is part of Sambas Malay society in displaying their identity through cultural phenomena that have been ingrained. Kemponan is broadly one of the ways people respect people who touchingly give food or drink. If it refers to the Malay community Sambas kemponan's beliefs, touching the food or drink offered, and if not done then it will get disaster (Mustansyir 2015:134-35). The relevance of kemponan with the early childhood education of Sambas Malay society in Batu Makjage Village in educating children some parents apply kemponan in children's daily lives. One of the applications in kemponan that is done to early childhood in Batu Makjage Village when parents offer children to eat while the child still wants to play or be outside the house then the parents will touch a little food or drink in the child's lips or in the hands of the child.

The purpose of parents is to instill kemponan so that children respect others' gifts and their parents. Especially early childhood in Batu Makjage Village at certain times playing outdoors. When the child is offered food and refuses to give his parents, the child is trained to respect the parents by accepting the gift even if it is touched only slightly. Parents also train their children so that children respect other people's gifts so as not to refuse and appreciate the feelings of others. The Sambas Malay society still uses kemponan as a form of collective memory as something that should not be violated so as not to be affected by disasters. Kemponan applied to early childhood is the habitus of Sambas Malay society, especially by parents' mediative relations between the subjective world and the cultural world into which agents are born and where parents and children share. Kemponan that has become habitus is political mythology that is realized, symbolized, which turns to permanent disposition, both utter kemponan, feelings, and thoughts. While the principle symbolized to early childhood by deflating is put outside consciousness to not be touched by the transformation of willing and unintentional can not even be excreted (Jenkins 1992:108-9).

Although there is a tahayul (mystic) element that parents believe and absorbed by the child, kemponan is internalized through the family environment to maintain the prevailing social structure. Kemponan has become a collective memory so that for parents, kemponan becomes devolution as a social education media in this case, early childhood means that what is instilled through the tradition of kemponan is a form of appreciation for the intention of the host who serves dishes to be tasted by guests.

\section{Early Childhood Education through Tuang Minyak Tradition}

Early childhood education in Sambas Malay society is carried out through a tradition that has been going on for quite a long time. The ceremony in the Sambas Malay society in Batu Makjage Village made early childhood as actor in its implementation. As for the tradition that lasts until now, one of them is tuang minyak. Tuang minyak tradition is a ritual performed by Sambas Malay society in the seventh month of a mother's womb. In the procession tuang minyak parents who carry it out must prepare forty kinds of fruits and then cut into containers and made into 
one and one egg. Besides, parents should also prepare seven strands of cloth consisting of five strands of long cloth and two strands of short cloth consisting of black and white fabrics. After that, the cloth is wrapped around the mother's abdominal area. After being recited a prayer by the shaman with children, both parents ate the fruits that had been prepared in the procession of tuang mimyak (Interview with Simus, February $2^{\text {nd }}$ 2020).

Based on the informant's statement that the tuang minyak tradition is part of the procession in the early childhood education stage even fall into the category of parenting through local tradition beliefs (ethnoparenting) due to early childhood from 0 to 6 years. The main goal in the tradition of tuang minyak so that the child at birth does not drool. The belief of Sambas Malay society, especially women who are pregnant by carrying out seven months, will be spared this. Besides, tuang minyak is also a form of affection given to children even before they are born. Based on the results of interviews related to tuang minyak is the application of parents to children in instilling the value of affection. Local tradition run by Sambas Malay society is one of the local wisdoms of culture. Most pregnant women what women eat while pregnant can have long-term effects on children. Of course, this is done down and down from one generation to the next because it is rooted in religious and traditional beliefs. Tuang minyak practice is formed by various social, cultural, economic, and psychological factors in maintaining the culture adopted (Forestell and Mennella 2008:55-58).

After the next pregnancy, Sambas Malay society carries out tepung tawar or welcoming the birth of children. Tepung tawar is performed on the odd day after the child's birth as an expression of gratitude to god for the provision of children to him. Tepung tawar is generally done at other events, such as: Moving house, buying a new vehicle, circumcision, and others. Tepung tawar has the meaning of flour given prayer. in the tradition of early childhood saprahan become actors in the development of cultural values when the newborn and introduced with chants of praise to God especially in his reading there is a sentence of gratitude. When women own the child, the Sambas Malay society generally performs circumcision to girls and is an obligation. For Sambas Malay girls is an honor that must be maintained so that the restrictions related to a woman should be introduced to him as early as possible. Circumcision tradition carried out by Sambas Malay parents in Batu Makjage Village in its application aims to instill an attitude of shame to children. Of course, this is related to the value of shame that has become Sambas Malay society's culture. Daughters who are circumcised when they are two to three years old. The tradition performed by Sambas Malay society in Batu Makjage Village is part of parents' form in parenting through tradition.

\section{Cultural Contestation in} Ethnoparenting of Sambas Malay Society

Early childhood education in the family and community environment in Batu Makjage Village tends to experience a contestation of values of cultural values and modernity values. The contest here is related to ethnoparenting conducted by parents to children experiencing 
resistance to the value of modernity that has mushroomed in the joints of people's lives. Ethnoparenting Sambas Malay people in their social practices have their own way, for example: pantang larang, cerita rakyat, kemponan, dan tunjuk ajar. Through the application of ethnoparenting parents form habitus cognitive mental structure of a person who deals with his social relationships. Such structures arise from the consequences of the logical process of thinking agents. Mentally from the family environment that buys it and internalizes in a person with the scheme the agent (child) can appreciate and shape his social world (Bourdieu 2008:54; Kusmanto and Elizabeth 2018:40).

The contestation that occurs is as an arena (field) the agents or actors compete with each other in the fight for value. Pierre Bourdieu viewed the arena as a battleground or a market where various types of capital were used and disseminated. In this arena, agents or actors create strategies to protect and raise their class or identity. Of course, the position of the agent or actor is determined by capital, which bourdieu classified into economic capital, social capital (inter-individual relations), cultural capital (knowledge) and symbolic capital (honor) (Bourdieu 1993). Contestation in the arena (field) in the family environment makes a battle of values between cultural values (locality) and modernity inside the family arena. On the certain side, parents instill cultural values, but obstacles occur when modernity enters the family realm. Contestation occurs when the parents tell the child to worship, then the child still plays with the gadget so that the child tends to refuse the parents' orders. When parents order their children to study, the child prefers to play with gadgets because of the value that occurs in Sambas Malay society in Batu Makjage Village.

The contest took place in Sambas Malay society in Batu Village related to ethnoparenting conducted in the family environment as an arena in which there was a series of negotiations under social conditions in Batu Makjage Village. Early childhood education in the family and community environment in Batu Makjage Village has undergone changes due to the entry of new media such as the internet and social media, this categorization is based on the influence that enters the global orbit of the world where the flow of information, ideas and values affects them more openly and intensively. it is very possible to change. This tendency follows new space and meaning based on intense negotiations and contests involving the Sambas Malay society in Batu Makjage Village according to the interests and capital knowledge about early childhood education. The observations made show that in educating children is inseparable from gadgets in children's play activities.

When parents were chatting with other neighbors the researchers also saw the child playing gadgets. Some community homes also provide wifi, and children still in the early childhood category come to play with gadgets. The existence of Wifi and devices that began to mushroom in the Sambas countryside, on the other hand, made parents feel helped when working in rice fields and the majority of rice farming workers. Parents do not feel worried when their child is left at home because some informants say when the child is already holding a gadget, the child does not play far from home. 
When parents at home, whether it is fathers, mothers, grandparents in the house of Sambas Malay society can not afford to give children restrictions in the use of media, causing children to play with gadgets more often than the commands made by parents. The value of modernity dominates in the family which is a new level of habitus formed by parents which is built through awareness and logic of action that is in line with the perpetrator (child) which is reflected in individual and collective awareness regardless of other factors, namely through internalization. external barriers and possibilities. It means habitus is a shared experience shared by the agent as the subject even though it has their uniqueness (Bourdieu 2008:54). To counter the dominance of the value of modernity over cultural values in ethnoparenting there are at least a few steps in reducing the negative impact of new media used by children including parents can limit the amount of media at home, turn off the media at mealtimes and when no one watches and avoids eating while watching television, interacting with children about media use, and exemplifying the correct use of media (Brooks 2011:265-66).

\section{The Relevance of Ethnoparenting of Sambas Malay Society in the Present}

Ethno-parenting Sambas Malay parents become habitus for early childhood because both in the family and society are increasingly open as a strategy and capital (Bourdieu 1993; Jenkins 1992; Lubis 2016). Every family member and community should compete to devise a plan to secure their position to not be seen as violating the rules or collective agreements in the social ecological system, both families, communities, and schools. Strategies were also made to change their identity as members of society, such as conducting early childhood education that has become a chain of unity for Sambas Malay society. The strategy used in the field becomes a place of mediation between the values that are contested and form habitus in ethnoparenting Sambas Malay society. Of course, the debate is significantly determined by the composition of capital. The four capitals offered by Bourdieu for Sambas Malay society in Batu Makjage Village, determine the tendency in instilling cultural values in early childhood in negotiating identity. The existing capital for Sambas Malay parents in instilling cultural values is two, namely cultural capital (cultural) in the form of family intellectual heritage in Sambas Malay parents. Second, social capital is related to social networks between Malay people and each other in Batu Makjage Village (Jenkins 1992:106-24). Habitus, capital, and field become the determinant in Sambas Malay people's social practice in conducting early childhood education.

Early childhood education conducted by Sambas Malay people is an ethnoparenting model in the family environment. Education is a traditional way that has been going on for a long time. However, in the current context ethnoparenting or early childhood parenting through culture is still relevant or not for the current context. In a cultural context, there is a culture that is maintained and there is also a culture that must be abandoned based on this cultural pragmatism in early childhood education. Of course, the cultural values of the Sambas Malay community in Batu Makjage Village describe their taste based on choices determined by the level of capital they have. 
This taste is constructed into a perception in conducting early childhood education. Based on this tendency, Sambas Malay society in Batu Makjage Village put themselves and their groups into variants of fellow Sambas Malay society where they lived together. The inculturation in the Sambas Malay society in Batu Makjage Village made contact between the values of modernity and locality in one family arena. The meeting of the two values fused and fused and eventually formed a new habitus in early childhood. Cultural values that continue to be interpreted towards new habitus without discarding the identity of the Sambas. The insertion of modernity values in the education and early childhood care of Sambas Malay society in Batu Makjage Village makes a gradual shift in structure or system. Therefore, the Sambas Malay society in Batu Makjage Village which is a category of rural communities characterized by the following characteristics: 1) have a deeper and closer relationship; 2) The system of group life on a family basis; 3) Mostly live-in agriculture; 4) Homogeneous society, such as in terms of livelihoods, religions, customs and others. Sambas Malay society who has the character of rural society changed in attitude to become a semi-urban society with the characteristics of consumptive nature and an individualistic society (Muhammad 2017:139-63).

The contestation of the value of giving birth to dislocation is a shift in Malay values in Batu Makjage Village has an effect in educating early childhood or ethnoparenting that is carried out by shifting or losing essential elements related to early childhood education. However, interestingly, Sambas Malay society in Batu Makjage Village did not realize how big the impact of value contestation occurred. The dislocation will affect
Sambas Malay identity in early childhood. Of course, to secure one's identity in a disruptive digital age requires early childhood to have cultural capital in the form of culture provided in the family environment and parents' education. Early childhood social interaction with the community around the environment becomes the social capital in competence in facing the times' challenges. Therefore, ethnoparenting carried out experienced resistance from new media in parenting to form a new habitus early childhood. So that the penetration of information technology is a media hegemony and dominates in the life of children amid ethnoparenting carried out by Sambas Malay parents in Batu Makjage Village.

Social changes that occur especially since the existence of information technology in ethnoparenting Sambas Malay society in Batu Makjage Village both gadgets and Wifi actually stimulate the growth of different behaviors and lifestyles. The lifestyle forms habitus, an urban lifestyle that has dominated early childhood education in the family environment. Changes in children's behavior can be seen from the request of children playing gadgets and asking for money to go to stalls containing wifi. The social change that occurred as a consequence of the Sambas Malay society's inability to avoid the penetration of modernity values in forming a new habitus or changing the value system and way of life. Traditionally instilled values compete with the value of modernity. If it continues to happen, the impact of new media in parenting will change the structure in the Sambas Malay family in Batu Makjage Village originally extended family, tending towards the core family (nuclear family), even to the single-family (single parent family). Even more severe results will result in between 
early childhood and parents experiencing loose family relationships (Kartika, Herawati, and Ulfah 2013:82).

Besides, the application mentioned by the public as ethnoparenting media in the current context is just a ceremonial event to maintain the identity of Sambas Malay society to remain recognized as from the other Sambas Malay society. Tuang minyak, tepung tawar, and circumcision of women who used to be considered sacred in instilling cultural values today with the current social change makes the traditional event in early childhood no more than ceremonial. The essence is not the tradition that becomes the media but how the pattern of Sambas Malay society in educating children, especially in the family becomes the basis in maintaining Malay identity. Besides, the modification of abstinence is not only to frighten children but can be changed to educate children and modifications by the intervention of God. Social changes that occur in Sambas Malay society in educating children are influenced by the contestation of values caused by people's taste for information technology by giving children gadgets or mobile phones, proving that the ethnoparenting of Sambas Malay society in Batu Makjage Village is shifting. Although in practice, parenting is not a distinction but resistance from lower middle-class society makes there is resistance in parenting both modernity and locality. The shifts in the value of Sambas Malay culture will later form a new habitus in Sambas Malay society's early childhood in Batu Makjage Village.

\section{Conclusion}

Habitus Sambas Malay people in ethnoparenting and early childhood education both diarena family and society. Strategies carried out in ethnoparenting by parents to children, namely: Tunjuk Ajar (tunjuk rasa, tunjuk lafal, and tunjuk laku), Pantang Larang, Kemponan, and tradition (tuang minyak, tepung tawar, and circumcision of girls). Habitus instilled in children is carried out in everyday life through a culture that is produced, perception, and evaluation of the practice of daily life of early childhood. Habitus will seep into the child's mind, feelings and aesthetics and determine the value of early childhood tastes based on the taste (flavor) of parents through ethnoparenting. Obstacles in ethnoparenting Sambas Malay people in the form of contestation of cultural values with modernity. The contestation gave birth to a dislocation that shifted Sambas Malay society's value in Batu Makjage Village to experience a shift or loss of essential elements related to early childhood education. The contestation that occurred in the early childhood education of Sambas Malay society in Batu Makjage Village experienced social changes that occurred since the existence of information technology. The current social change in the ethnoparenting of Sambas Malay society in Batu Makjage Village stimulates different behaviors and lifestyles. The lifestyle forms habitus, an urban lifestyle that has dominated early childhood education in the family arena.[]

\section{References}

Arif, Mahmud. 2015. "Islam, Kearifan Lokal, dan Kontekstualisasi Pendidikan: Kelenturan, Signifikansi, dan Implikasi Edukatifnya." AlTahrir: Jurnal Pemikiran Islam 15(1):67-90. doi: 10.21154/al-tahrir.v15i1.173.

Aslan, Aslan. 2017. "Nilai-Nilai Kearifan Lokal dalam Budaya Pantang Larang Suku 
Melayu Sambas." Jurnal Ilmu Ushuluddin 16(1):11-20. doi: 10.18592/jiu.v16i1.1438.

Bourdieu, Pierre. 1993. The Field of Cultural Production: Essays on Art and Literature. New York: Columbia University Press.

Bourdieu, Pierre. 2008. The Logic of Practice. California: Stanford University Press.

Bourdieu, Pierre. 2012. Arena Produksi Kultural Sebuah Kajian Sosiologi Budaya. Yogyakarta: Kreasi Wacana.

Brooks, Jane. 2011. The Process of Parenting. Yogyakarta: Pustaka Pelajar.

Dumais, Susan A. 2006. "Early Childhood Cultural Capital, Parental Habitus, and Teachers' Perceptions." Poetics 34(2):83-107. doi: 10.1016/j.poetic.2005.09.003.

Fernando, Joshua, and Rustono Farady Marta. 2019. "Resolusi Konflik Melalui Model Pengampunan Vita Activa Arendt dalam Komunikasi Generasi Muda Kalimantan Barat." Jurnal ASPIKOM 4(1):113-28. doi: 10.24329/aspikom.v4i1.511.

Forestell, Catherine A, and Julie A. Mennella. 2008. "Food, Folklore, and Flavor Preference Development." Pp. 55-64 in Handbook of Nutrition and Pregnancy. Totowa, NJ: Humana Press.

Granju, Katie Allison, and Betsy Kennedy. 1999. Attachment Parenting Instinctive Care For Your Baby and Young Child. New York: Pocket Books.

Hartini, Hartini, and G. Kartasapoetra. 2007. Kamus Sosiologi dan Kependudukan. Jakarta: Bumi Aksara.

Hermansyah, Hermansyah. 2010. Ilmu Gaib di Kalimantan Barat. Jakarta: Kepustakaan Populer Gramedia.

Hermansyah, Hermansyah. 2015. Islam dan Melayu di Borneo. Pontianak: IAIN Pontianak Press.
Jenkins, Richard. 1992. Pierre Bourdieu. London: Routledge.

De Jonge, Huub, and Gerben Nooteboom. 2006. "Why the Madurese? Ethnic Conflicts in West and East Kalimantan Compared." Asian Journal of Social Science 34(3):45674. doi: $10.1163 / 156853106778048597$.

Kartika, Endang, Nenden Ineu Herawati, and Ulfah Ulfah. 2013. "Bimbingan Sosial Anak Usia Dini Berbasis Budaya Lokal." Cakrawala Dini: Jurnal Pendidikan Anak Usia Dini 4(2):78-86. doi: 10.17509/cd.v4i2.10387.

Klinken, Gerry Van. 2007. Communal Violence and Democratization in Indonesia: Small Town Wars. London \& Newyork: Routledge, Taylor \& Francis Group.

Kurniawan, Syamsul. 2015. Tradisi dan Kepercayaan Umat Islam di Kalimantan Barat. Yogyakarta: Samudra Biru.

Kurniawan, Syamsul. 2018. "Pantang Larang and the Environmental Wisdom of Sambasness Malay in the Sepinggan Vilage." Kalam 12(1):87-104. doi: 10.24042/klm.v12i1. 1882.

Kurniawan, Syamsul, and Bayu Suratman. 2018. "Bertani Padi dan Etos Kerja Petani Perempuan dari Suku Melayu Sambas." Raheema: Jurnal Studi Gender dan Anak 5(1):51-59. doi: 10.24260/raheema.v5i1. 1090.

Kusmanto, Thohir Yuli, and Misbah Zulfa Elizabeth. 2018. "Struktur dan Sistem Sosial pada Aras Wacana dan Praksis." JSW Jurnal Sosiologi Walisongo) 2(1):39-50. doi: 10.21580/jsw.2018.2.1.2252.

Lubis, Akhyar Yusuf. 2016. Postmodernisme: Teori Dan Metode. Jakarta: Rajawali Press.

Mahdi, Adnan. 2019. "Religious Education Model for Children Age of Pre School in Family Melayu Sambas." International Journal of Education, Psychology and Counseling 
4(31):333-49. doi: 10.35631/IJEPC. 4310029 .

Masmuri, Masmuri, and Suratman Bayu. 2019. "Revitalisasi Masjid dalam Membangun Karakter pada Komunitas Melayu Sambas." Intizar 25(1):9-18. doi: 10.19109/intizar. v25i1.3238.

McLean, Deborah L. 1997. "Lessons in Living: Incorporating Folklore into Young Children's Lives."

Muhammad, Nurdinah. 2017. "Resistensi Masyarakat Urban dan Masyarakat Tradisional dalam Menyikapi Perubahan Sosial." Substantia: Jurnal Ilmu-IImu Ushuluddin 19(2):149-68. doi: 10.22373/substantia. v19i2.2882.

Mustansyir, Rizal. 2015. Kearifan Lokal Masyarakat Melayu Sambas dalam Tinjauan Filosofis. Yogyakarta: Fakultas FilsafatUGM.

Nurbayani, Nurbayani. 2015. "Pembinaan Iklim Kasih Sayang terhadap Anak dalam Keluarga." Jrnal Pendidikan Anak Bunayya 1(2):39-57.

Otoo, Patience, Helen Habib, and Augustine Ankomah. 2015. "Food Prohibitions and Other Traditional Practices in Pregnancy: A Qualitative Study in Western Region of Ghana." Advances in Reproductive Sciences 3(3):41-49. doi: 10.4236/arsci.2015. 33005.

Polcari, Ann, Keren Rabi, Elizabeth Bolger, and Martin H. Teicher. 2014. "Parental Verbal Affection and Verbal Aggression in Childhood Differentially Influence Psychiatric Symptoms and Wellbeing in Young Adulthood." Child Abuse \& Neglect 38(1):91-102. doi: 10.1016/j.chiabu.2013. 10.003.

Prasojo, Zaenuddin Hudi, Elmansyah Elmansyah, and Muhammed Sahrin Haji Masri. 2019. "Moderate Islam and the Social Con- struction of Multi-Ethnic Communities." Indonesian Journal of Islam and Muslim Societies 9(2):217-39. doi: 10.18326/ijims. v9i2.217-239.

Salim, Moh. Haitami. 2012. Islam dan Etnisitas: Menggali Nnilai-Nilai Kearifan Lokal Masyarakat Muslim di Kalimantan Barat. Pontianak: STAIN Pontianak Press.

Salim, Moh. Haitami. 2013. Nilai-Nilai Pendidikan Islam dalam Upacara Adat Melayu Pontianak. Pontianak: STAIN Pontianak Press.

Schulze, Kirsten E. 2017. 'The 'Ethnic' in Indonesia's Communal Conflicts: Violence in Ambon, Poso, and Sambas." Ethnic and Racial Studies 40(12):2096-2114. doi: 10.1080/01419870.2017.1277030.

Soekamto, Soerjono. 1993. Kamus Sosiologi. Jakarta: Rajawali Press.

Stewart, Frances. 2002. "Root Causes of Violent Conflict in Developing Countries." BMJ: British Medical Journal 324(7333):342345. doi: $10.1136 / \mathrm{bmj} .324 .7333 .342$.

Suratman, Bayu. 2019. “Pendidikan Anak Usia Dini Berbasis Kearifan Lokal pada Suku Melayu Sambas." Jurnal Noken: Ilmu-Ilmu Sosial 4(2):107-17. doi: 10.33506/jn.v4i2.436.

Swettenham, Frank. 2003. Perihal Orang Melayu. Kuala Lumpur: Penerbit Universiti Malaya.

Wahab, Hamidah Abdul. 2013. "Petua dan Pantang Larang Tradisional dalam Alam Melayu Sarawak." International Journal of the Malay World and Civilisation (Iman) 1(1):89-97.

Yusriadi, Yusriadi. 2015. "Identitas Orang Melayu di Hulu Sungai Sambas." Khalustiwa: Journal of Islamic Studies 5(1):74-99. doi: 10.24260/khatulistiwa.v5i1.267.

Yusriadi, Yusriadi. 2018a. "Bahasa dan Gender dalam Masyarakat Melayu di Pedalaman Kalbar." Raheema: Jurnal Studi Gender dan 
Bayu Suratman, Mahmud Arif

Anak 5(2):163-172. doi: 10.24260/ raheema.v5i2.1264.

Yusriadi, Yusriadi. 2018b. "Identitas Dayak dan Melayu di Kalimantan Barat." Handep:
Jurnal Sejarah dan Budaya 1(2):1-16. doi: 10.33652/handep.v1i2.10.

Zein, Abdul Baqir. 1999. Masjid-Masjid Bersejarah di Indonesia. Jakarta: Gema Insani Press. 